in our two patients that a much higher proportion of the dose of clioquinol is absorbed.

Haskins, Luttermoser \& Brady (1950) investigated the absorption and distribution of iodine after the oral administration of clioquinol to rabbits and suggested that this drug was absorbed, and eliminated, without degradation and without the liberation of inorganic iodine having occurred to any great degree. In human studies using clioquinol labelled with radio-active iodine, Liewendahl \& Lamberg (1967) confirmed that a high proportion of the dose was absorbed from the gut. These workers also showed that, in rats, much of the drug was taken up by the thyroid gland in the unchanged form (Lamberg \& Liewendahl, 1967). Iodine derived from the clioquinol was rapidly incorporated into the iodotyrosine precursors of thyroid hormone. This latter observation may explain why, although clioquinol interferes with the thyroidal uptake of iodine (Henderson Smith, 1964), no case of hypothyroidism attributed to clioquinol therapy has been recorded. Another possible risk of treatment with this drug is retinal damage (Lancet, 1968). The present cases suggest that very long-term application of clioquinol to extensive skin lesions should be embarked upon with caution.

The high levels of PBI found after clioquinol treatment are due in part to protein-binding of the drug as well as to contamination of the serum by inorganic iodine (Liewendahl \& Lamberg, 1968). Although normal PBI levels were regained by our patients within 3 weeks of the cessation of treatment, the work of Thorén (1960), Levin et al. (1966), and Sonksen et al. (1968) suggests that this estimation is probably valueless as a test of thyroid function for at气 least 2 months after oral administration of clioquinol.

\section{References}

FIEWEL, M. (1969) Percutaneous absorption of topical $\overrightarrow{\vec{F}}$ steroids in children. British Journal of Dermatology, $81 \stackrel{+}{+}$ suppl. 4, 113.

HASKINS, W.T., LUTTERMOSER, G.W. \& BRADY, F.J. (1950)흐 The physiological disposition of Diodoquin, Vioform, and $\bar{\omega}$ Chiniform in the rabbit as determined with radioiodine. $\overrightarrow{\mathbb{D}}$ American Journal of Tropical Medicine, 30, 599.

HENDERSON SMITH, S.L. (1964) Drugs and investigations. British Medical Journal, 2, 1265.

LAMBerG, B.-A. \& LiewendahL, K. (1967) Transfer of the $\vec{\circ}$ iodine of the iodochloroxyquinoline molecule (Vioform) $\overrightarrow{\vec{H}}$ to the iodo-amino acids of the thyroid gland. Nuclear $\vec{\omega}$ Medizin, 6, 16.

LANCET (1968) Annotation-Clioquinol and other halo? genated hydroxyquinolines. i, 679.

LeVIN, K., JosephSON, B. \& GRUNewald, G. (1966) The" effect of iodochlorooxyquinoline and iopanoic acid on the $₹$ determination of PBI and BEI. Acta endocrinologicair Copenhagen, 52, 627.

LIEWENDAHL, K. \& LAMBERG, B.-A. (1967) Metabolism of $\mathrm{G}$ iodochloroxyquinoline in man. Nuclear Medizin, 6, 20.

LIEWENDAHL, K. \& LAMBERG, B.-A. (1968) Clioquinol and $\sigma$ thyroid-function assessment. Lancet, ii, 979.

SARKANY, I. \& HADGRAFT, J.W. (1968) The influence offormulation on topical corticosteroid activity. British Journal of Dermatology, 81, suppl. 4, 98.

Scoggins, R.B. \& Kliman, B. (1965) Percutaneous absorp-tion of corticosteroids. New England Journal of Medicine, $\vec{v}$ 273, 831 .

SonkSEn, P.H., Ekins, R.P., Stevens, H.G., Williams, Es. \& NABARRO, J.D.N. (1968) Serum-levels of protein-bound iodine and thyroxine after a course of clioquinol. Lances, ii, 425.

THOREN, A. (1960) The influence of iodide and iodized com-잉 pounds on the PBI and the 131-I tracer test with specialo reference to various biologic states of the thyroid. Acta@ endocrinologica Copenhagen, 35, 351.

\title{
Metabolic alkalosis treated with intravenous hydrochloric acid
}

\author{
F. X. M. BEACH \\ M.B., Ch.B., M.R.C.P., D.T.M. \& H. \\ E. SHERWOOD JONES \\ Ph.D., F.R.C.P. \\ Intensive Care Unit and Clinical Pharmacology Unit (University of Liverpool) \\ Whiston Hospital, Prescot, Lancashire
}

IN CLINICAL practice, a severe metabolic alkalosis is found less frequently than a severe metabolic acidosis. In both disturbances the treatment consists of removing the cause and correcting the deficits or excesses in the body fluids. The severe metabolic acidosis of diabetic coma or that which follows cardiac arrest often needs urgent correction by giving sodium bicarbonate intravenously. In contrast, a metabolic alkalosis very rarely causes an immediate threat to life. In two patients recently admitted to this unit, the metabolic alkalosis required specific $\stackrel{N}{\sim}$ treatment with intravenous hydrochloric acid.

\section{Laboratory methods}

pH was determined electrometrically using $a$ ? capillary electrode (Siggaard-Andersen et al., 1960). The electrode was calibrated with two phosphate buffers of $\mathrm{pH} 7.416$ and 6.839 at $38^{\circ}$ (Semple, $\stackrel{+}{+}$ Mattock \& Uncles, 1962). The normal range was taken as $7 \cdot 35-7 \cdot 45$. 
$\mathrm{PaCO}_{2}$ was measured directly with an electrode (Severinghaus \& Bradley, 1958), calibrated with two gas mixtures, the $\mathrm{CO}_{2}$ contents of which were determined on the Haldane apparatus (Douglas \& Priestley, 1948). Normal values were taken as $33-44$ $\mathrm{mmHg}$. An aliquot of the arterial sample was centrifuged in a tube sealed by a thin layer of neutral mineral oil (Van Slyke, Weisiger \& Van Slyke, 1949) and a rubber vaccine closure. The plasma was quickly separated for the determination of sodium, potassium, chloride and total $\mathrm{CO}_{2}$. The latter was measured in duplicate on the AutoAnalyzer by the method of Skeggs (1960). The plasma bicarbonate was calculated from the total $\mathrm{CO}_{2}$. The normal value for healthy subjects at rest was found to be $22 \cdot 4 \pm$ $1.86 \mathrm{mEq} / 1$. When it was impossible to measure the plasma bicarbonate this was calculated from the Hendersen-Hasselbalch equation using a nomogram of Siggaard-Andersen (1963). We have used the acid-base terminology of Peters \& Van Slyke (1931). Sodium and potassium were measured on an internal-standard flame photometer and chloride electrometrically. The $95 \%$ confidence limits for healthy subjects were: serum sodium 136-147 $\mathrm{mEq} / 1$, potassium $3 \cdot 7-4.6 \mathrm{mEq} / \mathrm{l}$, chloride $100-110$ $\mathrm{mEq} / 1$ (Thompson \& Jones, 1965).

\section{Fluid therapy, acid therapy and nutrition}

Intravenous infusions containing sodium, potassium and chloride were used to correct the deficits of electrolyte. Calories and nitrogen were given as dextrose, fructose, ethanol, amino acids and fat emulsion (Peaston, 1966). An ampoule of Analar hydrochloric acid (British Drug Houses Concentrated Volumetric Solution No. 18005) was diluted in water for injection BP to give a normal solution.
Fifty millilitres of this solution was substituted for 50 $\mathrm{ml}$ of $5 \%$ dextrose removed from a litre container. The dextrose solution containing $100 \mathrm{mEq}$ of hydrochloric acid/l was given by slowinfusion through a peripheral vein as detailed in Table 2 .

\section{Case 1}

A man aged 61 developed pancreatitis after cholecystectomy. There was shock and 181 of fluid were aspirated from the stomach during 3 days. The serum amylase was 1200 Somogyi units $/ 100 \mathrm{ml}$. During the first 5 postoperative days the patient was given the following intravenous fluid therapy: water 16.7 1, sodium $2933 \mathrm{mEq}$-as chloride except for 80 $\mathrm{mEq}$ as bicarbonate, potassium $130 \mathrm{mEq}$; but only 300 calories were available and no nitrogen was given. The patient was critically ill when transferred on the fifth day to our Intensive Care Unit. He showed dehydration, hypotension, cyanosis, shallow breathing and a minute volume of less than 51 . The chest radiograph and electrocardiogram were normal.

The arterial blood (Table 1 ) and a $\mathrm{pH}$ of $7 \cdot 55$, high bicarbonate and hypercapnia, that is the metabolic alkalosis was incompletely compensated. There was hypochloraemia, hypokalaemia, uraemia and a small increase in plasma sodium. The urine was alkaline due to a high concentration of bicarbonate, the concentrations of sodium and potassium were normal but the urea content was low and the U/P ratio for urea was $6 \cdot 0$.

The initial fluid therapy consisted of solutions containing hydrochloric acid, sodium, potassium, chloride, dextrose, fructose, ethanol, amino acids and a fat emulsion. The amounts of each given during the first few hours are shown in Table 2. Oxygen therapy was given by means of an MC mask.

TABLE 1. Biochemical findings on admission to the Intensive Care Unit

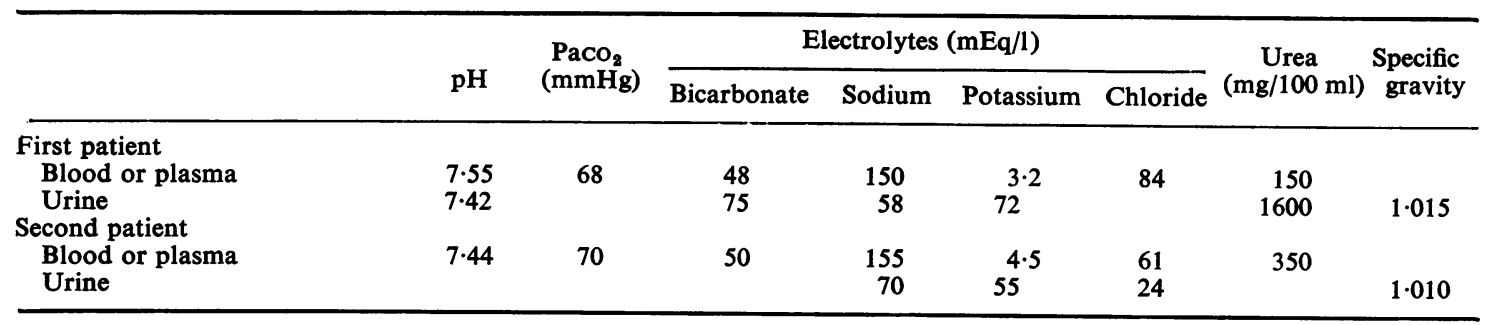

TABLE 2. Initial fluid therapy and nutrition

\begin{tabular}{|c|c|c|c|c|c|c|c|c|}
\hline & Time & $\begin{array}{l}\text { Water } \\
\text { (1) }\end{array}$ & $\begin{array}{l}\text { Sodium } \\
\text { (mEq) }\end{array}$ & $\begin{array}{l}\text { Potassium } \\
\quad(\mathrm{mEq})\end{array}$ & $\begin{array}{c}\text { Chloride } \\
\text { (mEq) }\end{array}$ & $\begin{array}{c}\text { Hydrion } \\
\text { (mEq) }\end{array}$ & Calories & $\begin{array}{c}\text { Nitrogen } \\
\text { (g) }\end{array}$ \\
\hline First patient & $\begin{array}{l}\text { Day } 1,4 \text { p.m. to } 10.30 \text { p.m. } \\
4 \text { p.m. of Day } 1 \text { to }\end{array}$ & $1 \cdot 68$ & 96 & 44 & 166 & 40 & 787 & $1 \cdot 1$ \\
\hline Second patient & $\begin{array}{l}10 \text { a.m. of Day } 2 \\
5 \text { p.m. of Day } 1 \text { to }\end{array}$ & $4 \cdot 45$ & 326 & 139 & 556 & 100 & 2074 & $7 \cdot 1$ \\
\hline & 8 p.m. of Day 2 & $4 \cdot 63$ & 181 & 40 & 367 & 150 & 3304 & $2 \cdot 1$ \\
\hline
\end{tabular}


After $6 \frac{1}{2} \mathrm{hr}$ the general state of the patient had improved. The minute volume was then 81 and the $\mathrm{PaCO}_{2}$ and plasma bicarbonate had fallen by 15 $\mathrm{mmHg}$ and $12 \mathrm{mEq} / 1$ respectively. (Table 3 ) During this time the patient was given $40 \mathrm{mEq}$ hydrochloric acid. After $18 \mathrm{hr}$ of fluid therapy $100 \mathrm{mEq}$ hydrochloric acid had been used together with the other electrolytes and food shown in Table 2 . The blood then showed a normal pH but raised $\mathrm{PaCO}_{2}$ and bicarbonate. During the evening of the second day of intensive care (postoperative Day 6) there was deterioration and shock recurred. Improvement followed infusions of 'Macrodex' $6 \%$ given to restore the blood pressure and central venous pressure, together with hydrocortisone. During Days 3 and 4 the patient was better and well enough to sit out of bed for a short time. The temperature fell to normal and the gastric aspirate decreased. On Day 3 the arterial blood showed a mild metabolic alkalosis with moderate hypercapnia. The alkalosis was still present on Day 4 but the $\mathrm{PaCO}_{2}$ was then normal (Table 3). The intakes of water, sodium, potassium and chloride and the losses of water, sodium and potassium are given in Table 3.

The good progress was not maintained and fever, hypotension and a large gastric aspirate recurred. The patient died on the eleventh postoperative day when the blood findings were: $\mathrm{pH} 7 \cdot 48, \mathrm{PaCO}_{2} 36$ $\mathrm{mmHg}$ and bicarbonate $27 \mathrm{mEq} / 1$, plasma sodium $161 \mathrm{mEq} / 1$, plasma potassium $5.8 \mathrm{mEq} / 1$, blood urea $232 \mathrm{mg} / 100 \mathrm{ml}$, blood sugar $1000 \mathrm{mg} / 100$ $\mathrm{ml}$, serum amylase 800 Somogyi units $/ 100 \mathrm{ml}$, haemoblobin $50 \%$. Acute pancreatitis and generalized peritonitis were found at necropsy.

\section{Case 2}

A man aged 48 with a chronic peptic ulcer developed persistent vomiting due to pyloric obstruction. His habit was to take $800-1000 \mathrm{mEq}$ of alkali each day as magnesium hydroxide and carbonate. The patient was restless and confused, emaciated and dehydrated. Respirations were slow and shallow. The blood pressure was 100/60 and the ECG showed atrial fibrillation. Radiographs of the chest and abdomen were normal. The blood (Table 1) showed a fully-compensated metabolic alkalosis with severe hypercapnia. There was hypernatraemia, severe hypochloraemia and uraemia. The urine had a normal specific gravity, normal concentrations of sodium and potassium but a low chloride content.

During the first $27 \mathrm{hr}$ the patient was given 150 $\mathrm{mEq}$ of hydrochloric acid together with the other electrolytes and food shown in Table 2. Oxygen therapy was given by means of an MC mask. During this period the patient improved generally and alveolar ventilation increased, the $\mathrm{PaCO}_{2}$ falling by $10 \mathrm{mmHg}$. The plasma bicarbonate fell from 50 to
$34 \mathrm{mEq} / 1$ and there was a small increase in the plasma chloride, which remained low. The plasma potassium was normal. By the third day the patient was greatly improved and was able to sit out of bed. The blood showed a normal $\mathrm{pH}$ and $\mathrm{PaCO}_{2}$ and the plasma bicarbonate was only slightly raised. The intakes of water, sodium, potassium and chloride and the losses of water, sodium and potassium are given in Table 3. Persistent uraemia attributed to tubular damage was treated by 5 days of peritoneal dialysis.

Pyloroplasty and vagotomy (Mr R. Brearley, $\vec{\circ}$ F.R.C.S.) was carried out on the thirteenth day and $\vec{\overrightarrow{ }}$ convalescence was trouble-free. Three months later $\omega$ the patient was symptomless. The blood urea was $32 \frac{\text { a }}{\circ}$ $\mathrm{mg} / 100 \mathrm{ml}$, creatinine clearance $125 \mathrm{ml} / \mathrm{min}$ and the acidification test of Wrong \& Davies (1959) gave a urinary $\mathrm{pH}$ of $5 \cdot 2$. Spirometry, lung volumes and transfer factor (Dr C. M. Ogilvie) were normal.

\section{Discussion}

In the first patient, who had severe pancreatitis, the alkalosis was probably due to loss of chloride as gastric acid and sodium chloride together with potassium depletion and the administration of sodium bicarbonate. In the patient with pyloric obstruction, $\vec{\varphi}$ the alkalosis was caused by loss of gastric acid, $\&$ large intake of alkali and potassium depletion due the starvation.

In both patients respiratory compensation of the alkalosis was complete or nearly so. This extreme compensation caused severe respiratory failure, which of itself, was a serious threat to life. The laboratory measurements show that, to determine the effects of an alkalosis, it is necessary to measure $\mathrm{pH}$ and $\mathrm{PaCO}_{2}$. It is also preferable to measure bicarbonate rather than calculate this value from the Henderson-Hasselbaich equation. In a separate study we have confirmed that, in disease, large differences exist between the plasma bicarbonate measured and the value calculated from the Henderson-Hasselbalch equation. The finding of severe hypercapnia in the blood of a 'surgical' patient is a pitfall because the hypercapnia could be wrongly interpreted as the prime disorder of acid-base balance. It would be illogical and dangerous to lower the $\mathrm{PaCO}_{2}$ by artificial respiration. We believe that the respiratory failure caused by the metabolic alkalosis required specific treatment with hydrochloric acid. The acid therapy was included in the fluid therapy and nutrition used to replace deficits of water, sodium and potassium and to provide calories and nitrogen. This made it impossible to prove that hydrochloric acid alone improved alveolar ventilation; the observations do however, strongly suggest that hydrochloric acid increased ventilation. 


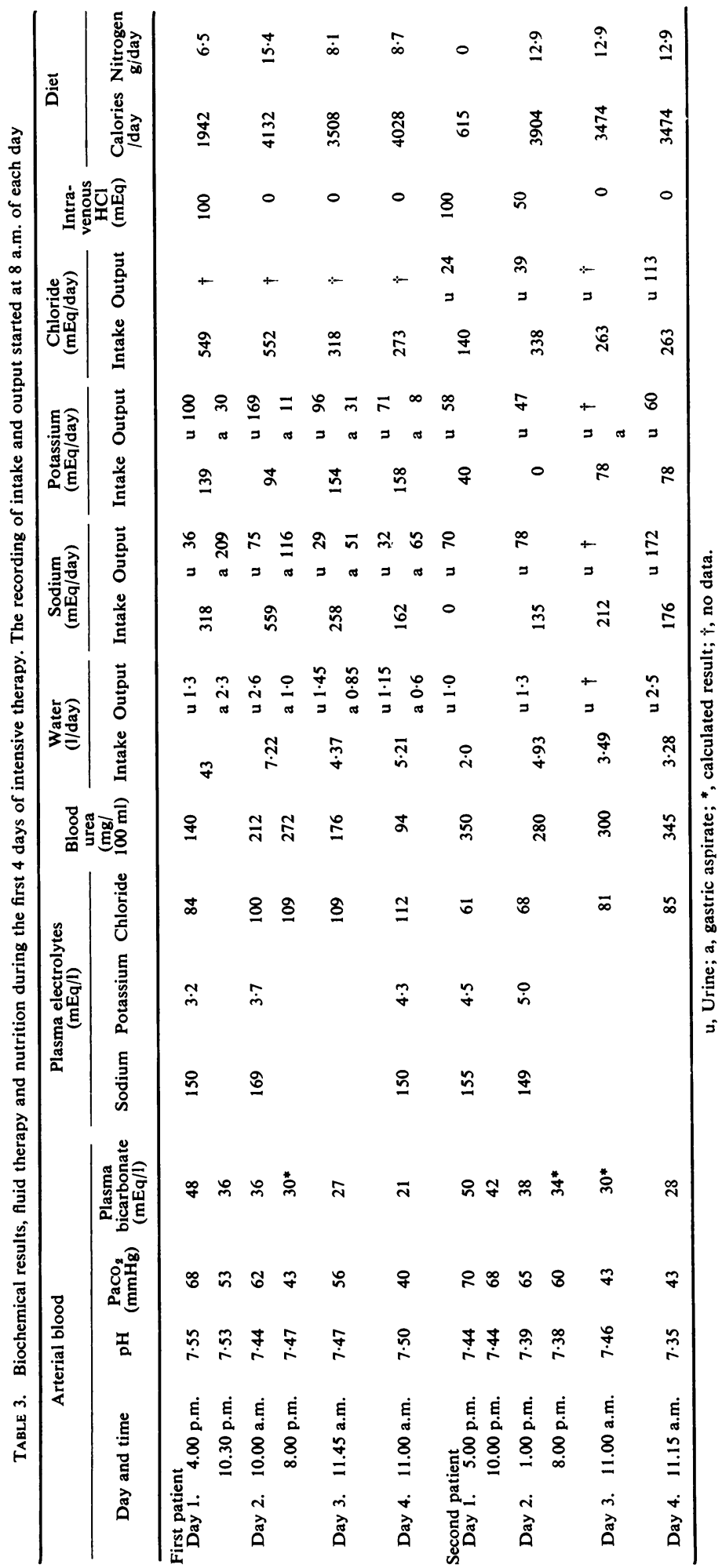


TABLE 4. Acid therapy used to treat metabolic alkalosis

\begin{tabular}{|c|c|c|c|c|}
\hline \multirow[b]{2}{*}{ References } & \multirow[b]{2}{*}{ Cause of alkalosis } & \multirow{2}{*}{$\begin{array}{l}\text { Intravenous } \\
\text { hydrochloric } \\
\text { acid (mEq) }\end{array}$} & \multicolumn{2}{|c|}{ Patients treated } \\
\hline & & & $\begin{array}{l}\text { Number } \\
\text { treated }\end{array}$ & $\begin{array}{l}\text { Number } \\
\text { survived }\end{array}$ \\
\hline Elkington \& Danowski (1955) & Ileus and acute renal failure & $\begin{array}{r}50 \\
700\end{array}$ & 1 & 0 \\
\hline Frick \& Senning (1963) & Ileus & $\begin{array}{l}765 \\
500\end{array}$ & 3 & 2 \\
\hline Girardet (1967) & Pyloric stenosis & No data & 1 & 1 \\
\hline Bradham (1968) & Trans-lumbar amputation & No data & 1 & 1 \\
\hline
\end{tabular}

In other patients admitted to this unit with a metabolic alkalosis, respiratory compensation has been slight or absent. These patients showed tetany which, when associated with coma and convulsions, was an immediate threat to life. We suggest that when a metabolic alkalosis causes either severe respiratory failure or severe tetany, intravenous hydrochloric acid is a valuable and safe addition to conventional fluid therapy. We found no reference to these indications for using hydrochloric acid therapy. Frick \& Senning (1964) advise hydrochloric acid therapy to treat a metabolic alkalosis when intravenous sodium chloride was contra-indicated because of acute renal failure with oliguria; a situation in which we would use dialysis. The scanty literature on the use of intravenous hydrochloric acid is shown in Table 4. Intravenous ammonium chloride has been used more often than hydrochloric acid but has the serious disadvantage of ammonium toxicity (Zintel, Rhoads \& Ravdin, 1943; Moore, 1959). Peritoneal dialysis has been successfully used to correct the metabolic alkalosis of pyloric obstruction (D. M. Morrison, personal communication).

In theory acetazolomide should accelerate removal of excess bicarbonate from the extracellular fluid into the urine but we have no information on this treatment. On the treatment of alkalosis, Black (1964) wrote 'I am doubtful if direct attack on alkalosis by giving acids (or potential acids such as ammonium chloride) is ever called for.' We think that there are rare exceptions to this opinion.

\section{References}

BlaCK, D.A.K. (1964) Essentials of Fluid Balance, 3rd edn. Blackwell Scientific Publications, Oxford.

BRADHAM, G.B. (1968) The intravenous use of hydrochloric acid in the treatment of severe alkalosis. American Surgery, $34,551$.

Douglas, C.G. \& Priestley, J.G. (1948) Human Physiology, 3rd edn. Oxford University Press, London.
Elkington, J.R. \& Danowski, T.S. (1955) The Body Fluids. Baillière, Tindall \& Cox, London.

Frick, P.G. \& SenNing, A. (1963) The treatment of severeo metabolic alkalosis with intravenous $\mathrm{N} / 10$ or $\mathrm{N} / 5$ hydro-3. chloric acid. Deutsche medizinische Wochenschrift, 88, 1924.

GIRARDET, P. (1967) Intravenous injection of hydrochloric ir acid in a case of serious metabolic hypochloraemic alkalosis. Rev. Med. Suisse, Rom. 87, 278.

MooRe, F.D. (1959) Metabolic Care of the Surgical Patient. W. B. Saunders, Philadelphia.

Peaston, M.J.T. (1966) Design of an intravenous diet of amino-acids and fat suitable for intensive patient care. $\subset$ British Medical Journal, 2, 338.

Peters, J.P. \& Van Slyke, D.D. (1931) Quantitative Clinical $\vec{\oplus}$ Chemistry. Baillière, Tindall \& Cox, London.

RAMPINI, S. \& FRICK, P.G. (1964) Intravenous hydrochlo인 acid in the treatment of hypochloraemic alkalosis. He vetica paediatrica acta, 19, 391.

Semple, S.J.G., Mattock, G. \& Uncles, R. (1962) A buffêtr standard for blood pH measurements. Journal of Biological Chemistry, 237, 963.

Severinghaus, J.W. \& Bradley, A.F. (1958) Electrodes for blood $\mathrm{Po}_{2}$ and $\mathrm{PCO}_{2}$ determination. Journal of Applied Physiology, 13, 515.

SiggAARD-ANDERSEN, O. (1963) Blood acid-base alignment nomogram. Scandinavian Journal of Clinical and Laboratory Investigation, 15, 211.

SiggaARd-Andersen, O., Engel, K., Jørgensen, K. \& AstruP, P. (1960) A micro method for the determination of $\mathrm{pH}$, carbon dioxide tension, base excess and standard bicarbonate in capillary blood. Scandinavian Journal of Cliniral and Laboratory Investigation, 12, 172.

SkegGS, L.T. (1960) An automatic method for the determination of carbon dioxide in blood plasma. American Journal of Clinical Pathology, 33, 181.

Thompson, G.S. \& JoNES, E.S. (1965) Errors in the measure- 은 ments of serum electrolytes. Journal of Clinical Pathology, $18,443$.

VAN SLYKe, D.D., WeISIGER, J.R. \& VAN SLYKe, K.K. (1949) Photometric measurement of plasma pH. Journal of $\mathrm{N}$ Biological Chemistry, 179, 743.

Wrong, O. \& DAvies, H.E.F. (1959) The excretion of acid in renal disease. Quarterly Journal of Medicine, 28, 259.

ZiNTEL, H.A., RhOADS, J.E. \& RAvDIN, I.S. (1943) The use of intravenous ammonium chloride in the treatment of alkalosis. Surgery, 14, 728. 